\title{
Food sources of energy and nutrients in the diets of infants and toddlers in urban areas of China, based on one 24-hour dietary recall
}

\author{
Huan Wang ${ }^{1}$, Liya Denney ${ }^{2^{*}}$, Yingdong Zheng ${ }^{1}$, Gerard Vinyes-Pares ${ }^{3}$, Kathleen Reidy ${ }^{4}$, Peiyu Wang ${ }^{1}$ \\ and Yumei Zhang ${ }^{1 *}$
}

\begin{abstract}
Background: Food sources of nutrients in young children in China have been little investigated. The objective of this study was to understand feeding patterns of young children through an analysis of food sources of energy and nutrients in the diets of infants and toddlers living in urban areas in China.

Methods: This study was part of the cross-sectional study, Maternal Infant Nutrition Growth (MING). One 24-h dietary recall was completed for a total of 1409 children (infants 6-11 months, younger toddlers 12-23 months, and older toddlers 24-36 months) via face-to-face interviews with the primary caregivers. All food, beverage and dietary supplements that the child consumed on the previous day were recorded and processed with a database including data from Chinese Food Composition tables. All reported foods and supplements were assigned to one of 83 food groups developed for the study. Percent contribution of each food group to nutrient intakes was calculated.
\end{abstract}

Results: Children in all 3 age groups received a majority of energy (52 to $69 \%$ ) from few foods including infant formula or growing-up (fortified) milk, rice, noodles, pork and eggs, with rice becoming the number one source of energy by 24 months. Rice and noodles were not only top sources of energy (17 to $26 \%$ ) and carbohydrate ( 27 to $40 \%$ ) but also top sources of protein (13 to $16 \%$ ), iron (13 to $18 \%$ ) and zinc (11 to $18 \%$ ). Supplements made substantial contributions to intakes of vitamin A, zinc, iron and calcium. Salt added during home-cooking was the main source of sodium (60 to $80 \%$ ).

Conclusions: Few foods made up the core of the diets of infants and young toddlers living in urban areas in China. Low nutrient-dense rice and noodles were top sources of many nutrients, which could potentially lead to inadequate intakes of some key nutrients.

\section{Background}

Early childhood is a time when food preferences and dietary habits are being established. The dietary patterns established during this time often persist into adulthood and have implications for developing diet-related chronic diseases later [1], such as cardiovascular disease and diabetes [2]. Knowledge about the sources of energy and nutrients in young children's diets can help health professionals to gain a more complete understanding about their diets and the specific strategies for improvement.

\footnotetext{
* Correspondence: liya.denney@rdls.nestle.com; zhangyumei@hsc.pku.edu.cn

${ }^{2}$ Nestlé Research Centre, Lausanne, Switzerland

${ }^{1}$ School of Public Health, Peking University, Beijing, China

Full list of author information is available at the end of the article
}

Food sources of energy and nutrients in young children have been studied in the US [3-6]. With a focus on the US infant and toddler population, the Feeding Infants and Toddlers Study (FITS) recently reported the sources of energy and 24 nutrients in detail and described shifts in major nutrient sources as children age [6]. Dietary sources of nutrients have also been studied in pre-school children in Belgium and Sweden [7, 8]. By comparison, such studies in China are very limited. To date, few published studies available in China only described the intake of one nutrient such as energy or fats or iron with limited information for food sources [9-11].

The current paper describes the major food sources of energy and nutrients among infants and toddlers in China 
using data from the Maternal Infant Nutrition Growth (MING) study, in which one 24-h dietary recall was collected from infants and toddlers (6 to 35 months of age).

\section{Methods}

Sample design and subjects

The MING study methods and sample will be subsequently described in detail. Briefly, the MING study was a cross-sectional study to investigate the dietary and nutritional status of pregnant women, lactating mothers and young children aged from birth up to 3 years. Infants and toddlers were recruited from maternal and child care centres in 8 tier 1 and tier 2 cities in China. Subjects were recruited randomly based on the child registration list in each of the maternal and child care centres (two in each city) until the target number was reached. Final samples sizes in three subgroups were 444 children 6 to 11 months (infants), 476 children 12 to 23 months (younger toddlers) and 489 children 24 to 35 months (older toddlers).

The study was conducted according to the guidelines in the Declaration of Helsinki. All of the procedures involving human subjects were approved by the Medical Ethics Research Board of Peking University (No.IRB0000105211042). Written informed consent was obtained from the primary caregiver of each infant or toddler participating in the study.

\section{Data collection methods}

One 24-h dietary recall was collected for each child by trained interviewers via face-to-face interviews with the primary caregiver. Interviewers asked the primary caregiver about all food, beverages and supplements that the child consumed on the previous day. Portions were estimated using measurement aids (including spoons, cups and bowls) and a picture booklet of common foods consumed in China (designed for national nutrition survey by the Centre of Disease Control in China). The information collected was then converted to weight in grams using a portion to weight conversion list for common foods. Use of nutrient supplements was also collected during the face-to-face interview with the primary caregiver as part of a general questionnaire. A list of dietary supplements commonly used in China was used to code the supplement(s) reported. The primary caregiver was also encouraged to bring the packing of the nutrient supplement to the interviewer. The information collected included the name and brand of the supplement, age when supplement was first given and the amount used.

Food records were entered and processed with a food composition database created for this study that included data from Chinese Food Composition (CFC) tables 2004 \& 2009 [12, 13] and branded baby food products and dietary supplements commonly consumed in China. CFC contains information of 1773 foods with 36 nutrients. The values for both beta-carotene and retinol were available in the database, thus vitamin A was estimated in retinol activity equivalents using the following formula [14]: Retinol activity equivalents $=\mu \mathrm{g}$ retinol $+1 / 2 \quad(\mu \mathrm{g}$ beta-carotene equivalents/6).

We did not collect data on the amount of human milk fed, but simply the number of times the mother nursed during the day and estimated the amount based on published literature [15]. For infants aged 6 to 11 months fed human milk as the sole milk source, the amount of human milk was assumed to be $600 \mathrm{~mL} /$ day; for partially breastfed infants, the amount of human milk was estimated as $600 \mathrm{~mL} /$ day minus the amount of formula or other milks consumed. For breastfed toddlers aged 12 to 23 months, the amount of human milk was estimated as $89 \mathrm{~mL}$ per feeding occasion; and for toddlers aged 24-35.9 months, the amount of human milk was estimated as $59 \mathrm{~mL}$ per feeding occasion [15].

\section{Analytic methods}

A comprehensive listing of dietary sources of nutrients was initially developed by Krebs-Smith and colleagues [16] and later expanded by other researchers [4, 17]. To make the results of the present study comparable with the information obtained in other countries, the classifications of food group were designed to be similar to those used by Fox and colleagues [6], but at same time reflect the characteristics of the Chinese diet by having traditional, frequently consumed foods listed individually such as noodles, steamed bread and Chinese cabbages. Thus, a list of 83 food groups including two for dietary supplements were created based on similarities in nutrient content and role in the diet (Table 1).

A total of 680 individual foods and supplements were reported by the caregivers in this study. These foods and supplements were assigned to one of the 83 groups except 16 food mixtures that were infrequently consumed such as hamburgers, pizzas, dumplings or sushi, etc. The 16 food mixtures were disaggregated into their ingredients, and the ingredients were then assigned to one of the 83 groups.

\section{Statistical analysis}

Statistical Analysis Software (version 9.2, 2008, SAS Institute, Inc, Cary, NC) was used to calculate the contribution of each food group to the overall intake of energy and nutrients. After all foods and supplements reported were assigned to one of the 83 groups, the weighted percentage contribution of each food group for all infants and toddlers was calculated by summing the amount of a given nutrient provided by each food group for all individuals and dividing by the total intake of that nutrient consumed by all individuals from all foods and supplements. Only foods/food groups that contributed over $1 \%$ of the nutrient intake are represented including 
Table 1 Food group classifications among infants and toddlers 6-35 months from the MING study

\begin{tabular}{|c|c|c|}
\hline Milk and milk products & Other grains/grain products ${ }^{\mathrm{e}}$ & Peaches/nectarines/plums \\
\hline Breast milk & Flour/baking ingredients ${ }^{f}$ & Pears \\
\hline Infant formula & Vegetables & Grapes \\
\hline Growing-up milk ${ }^{a}$ & Broccoli & Melons \\
\hline Milk $^{\mathrm{b}}$ & Chinese cabbages & Dried fruits \\
\hline Soy milk & Coles & Other fruits' \\
\hline Cheese & Celeries & 100 \% juice \\
\hline Yogurt & Carrots & Baby food fruits \\
\hline Meat/poultry/fish/meat alternates & Corn & Desserts and sweets \\
\hline Beef & Green beans & Cakes/pies \\
\hline Lamb & Eggplants & Cookies \\
\hline Sausages & Peas & Ice cream \\
\hline Pork & Potatoes & Honey \\
\hline Organ meats & Pumpkins & Chocolates \\
\hline Chicken/duck & Spinach & Candy \\
\hline Fish/shellfish/shrimps & Sweet potatoes/yams & $\begin{array}{l}\text { Sugar/syrups/jams/jellies/other } \\
\text { sweeteners }\end{array}$ \\
\hline Eggs $^{c}$ & Tomatoes/tomato sauce & Other desserts \\
\hline Other meat $^{d}$ & Pickles & Sweetened beverages \\
\hline Soy/tofu/meat substitutes & Other root vegetables ${ }^{g}$ & Other \\
\hline Nuts/seeds & Other leafy vegetables ${ }^{h}$ & Salad dressings/mayonnaise \\
\hline Baby food meat & Other baby food vegetables & Oil/other fats ${ }^{j}$ \\
\hline Grains and grain products & Fruits & Condiments $^{k}$ \\
\hline Infant cereal & Apples/applesauce & Chips/puffed food/other salty snacks \\
\hline Bread/biscuits & Apricots & Salts' \\
\hline Pancakes/sesame seed cakes & Kiwi fruits & Soups \\
\hline Noodles & Dragon fruits & Other beverages $^{\mathrm{m}}$ \\
\hline Rice & Mangoes & Supplements \\
\hline Millets & Jujube & Vitamin and mineral supplements \\
\hline Steamed bread & Bananas & Other supplements \\
\hline Cornmeal & Berries & \\
\hline Other baby food grains & Citrus fruits & \\
\hline
\end{tabular}

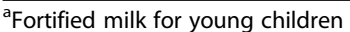

bIncludes cow's milk and goat's milk

Includes eggs reported separately and eggs included in disaggregated food mixtures

Includes donkey, horse, dog, rabbit and turkey meat

eIncludes buckwheat, barley, glutinous rice, highland barley and sorghum

fIncludes flour, corn-starch, yeast and baking powder included in disaggregated food mixtures

${ }^{9}$ Includes white radish, asparagus, water chestnut, lotus root, onion, winter squash and bean sprout, peppers, cucumbers, mushrooms and balsam pear

hIncludes Chinese leeks, baby cabbage, lettuce, coriander, fennel, heartleaf houttuymia herb, fiddlehead, crown daisy and Shepherd's purse

includes pineapple, cherries, papaya, hawthorn, persimmon, pomegranate, coconut and mangosteen

j'Includes olive oil, soybean oil, canola oil, lard oil, butter and fats included in disaggregated food mixtures

kIncludes shallot, garlic, ginger, Chinese red pepper, peppermint, vinegar, soy sauce and other condiment sauces

Includes cooking salts and salts included in disaggregated food mixtures

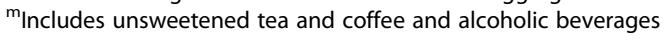

dietary supplements. Sources of energy and nutrients were assessed separately for infants aged 6 to 11 months, younger toddlers aged 12 to 23 months and older toddlers aged 23 to 35 months in descending order of contribution to overall nutrient intake.

\section{Results}

\section{Dietary supplements}

As reported by the caregivers, $57 \%$ of the young children received dietary supplements on the day of their 24-h dietary recall. The main types of supplements used 
were fish liver oil, multiple vitamin and mineral supplements.

\section{Energy, macronutrients and fibre}

The food sources of energy are displayed in Table 2 . The top 5 energy sources for infants aged 6 to 11 months were infant formula, breast milk, rice, eggs and noodles. For younger and older toddlers, the top 5 sources of energy were growing-up milk, rice, noodles, pork and eggs. The top 5 food sources of energy contributed 69, 59 and $52 \%$ of total energy in each of the age groups respectively (Fig. 1, Table 2), showing a decrease in milk product consumption along with an increase in dietary diversity as children grew older.

Infant formula (26\%) and breast milk (19\%) contributed $45 \%$ of total energy among infants. Rice and noodles were major contributors to energy, together providing an additional $17 \%$ of calories. Infant formula was replaced by growing-up milk as the number one and number two source of energy among younger and older toddlers respectively. Rice became the number one source of energy among older toddlers and was number two among the younger toddlers. Other foods in the top five sources of energy included noodles, pork and eggs (Fig. 1 and Table 2). After the top 5, other food sources of energy were infant cereal (infants only), oil/other fats, pancakes/ sesame seed cakes and milk and bread/biscuit (Table 2).
The top 5 food sources of energy were also the major sources of protein contributing 69 to $50 \%$ among the three age groups (Fig. 1 and Table 3). Infant formula and growing-up milk were the number one sources of protein among infants and younger toddlers respectively. Eggs were the most important non-milk source of protein, with the contribution ranging from 15 to $18 \%$ (Table 3). Rice, pork, fish/shellfish/shrimps and noodles were other major sources of protein.

Infant formula was the leading source of carbohydrate (21\%) among infants while growing-up milk was the number two and number three source of carbohydrate among younger and older toddlers respectively (Fig. 1 and Table 4). Rice was the number two source of carbohydrate among infants $(16 \%)$ and then became the number one source of carbohydrate contributing a quarter or more among younger and older toddlers. Noodles were also major sources of carbohydrate. Rice and noodles together accounted for 27 to $40 \%$ of carbohydrate intake among the children. Other important sources of carbohydrate were infant cereal among infants, pancakes/sesame seed cakes, bread/biscuits and apples/ applesauce among the children.

Table 5 shows changes in the sources of dietary fibre for the different age groups. Among infants 6 to 11 months, the number one source of dietary fibre was apples/applesauce and infant formula was number two,

Table 2 Sources of energy among infants and toddlers 6-35 months from the MING study

\begin{tabular}{|c|c|c|c|c|c|c|}
\hline \multirow[b]{2}{*}{ Rank } & \multicolumn{2}{|l|}{ Age 6-11 months } & \multicolumn{2}{|l|}{ Age 12-23 months } & \multicolumn{2}{|l|}{ Age $24-35$ months } \\
\hline & Food Group & $\%$ of Total & Food Group & $\%$ of Total & Food Group & $\%$ of Total \\
\hline 1 & Infant formula & 26 & Growing-up milk & 22 & Rice & 18 \\
\hline 2 & Breast milk & 19 & Rice & 15 & Growing-up milk & 11 \\
\hline 3 & Rice & 10 & Noodles & 8 & Pork & 9 \\
\hline 4 & Eggs & 7 & Pork & 7 & Noodles & 8 \\
\hline 5 & Noodles & 7 & Eggs & 7 & Eggs & 6 \\
\hline 6 & Infant cereal & 7 & Oil/other fats & 7 & Pancakes/sesame seed cakes & 6 \\
\hline 7 & Pancakes/sesame seed cakes & 3 & Pancakes/sesame seed cakes & 5 & Oil/other fats & 5 \\
\hline 8 & Oil/other fats & 3 & Milk & 4 & Milk & 5 \\
\hline 9 & Pork & 3 & Bread/biscuits & 3 & Bread/biscuits & 4 \\
\hline 10 & Bread/biscuits & 2 & Fish/shellfish/shrimps & 2 & Fish/shellfish/shrimps & 2 \\
\hline 11 & Apples/applesauce & 2 & Apples/applesauce & 2 & Soy/tofu/meat substitutes & 2 \\
\hline 12 & Bananas & 1 & Bananas & 2 & Chicken/duck & 2 \\
\hline 13 & Growing-up milk & 1 & Steamed bread & 1 & Apples/applesauce & 2 \\
\hline 14 & Steamed bread & 1 & Citrus fruits & 1 & Bananas & 2 \\
\hline 15 & - & & Breast milk & 1 & Nuts/seeds & 2 \\
\hline 16 & - & & Millets & 1 & Citrus fruits & 1 \\
\hline 17 & - & & Soy/tofu/meat substitutes & 1 & Steamed bread & 1 \\
\hline 18 & - & & Nuts/seeds & 1 & Yogurt & 1 \\
\hline 19 & - & & Chicken/duck & 1 & Cakes/pies & 1 \\
\hline
\end{tabular}




\section{6-11 months}

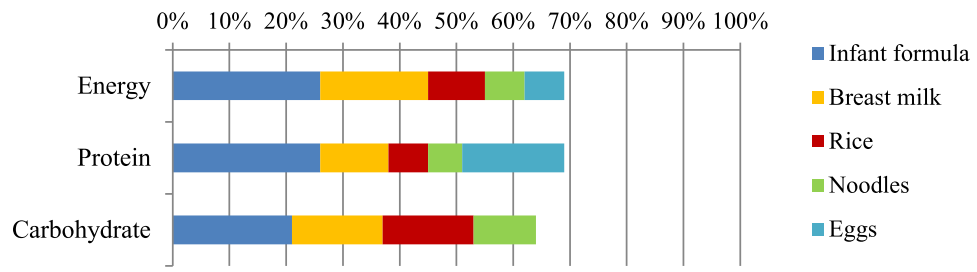

\section{2-23 months}

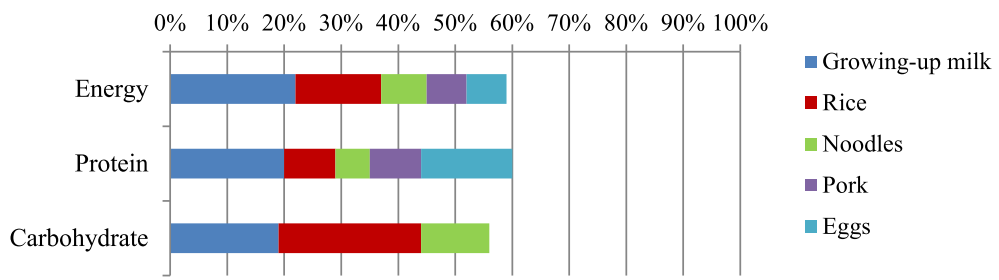

\section{4-35 months}

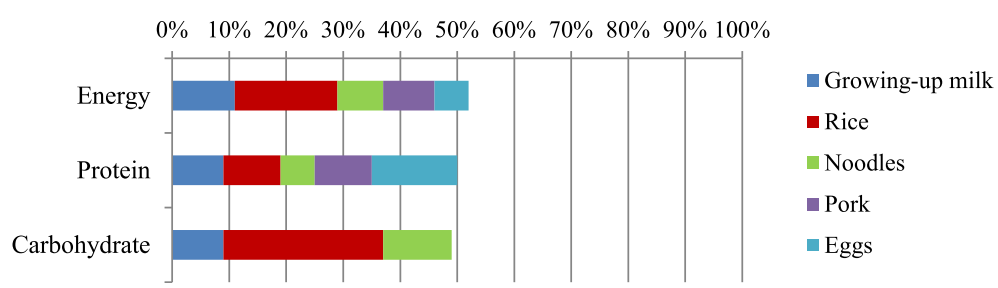

Fig. 1 Percent contribution of top 5 foods of energy to intakes of energy, protein and carbohydrate of infants and toddlers from the MING study

Table 3 Sources of protein among infants and toddlers 6-35 months from the MING study

\begin{tabular}{|c|c|c|c|c|c|c|}
\hline \multirow[b]{2}{*}{ Rank } & \multicolumn{2}{|l|}{ Age 6-11 months } & \multicolumn{2}{|l|}{ Age 12-23 months } & \multicolumn{2}{|l|}{ Age $24-35$ months } \\
\hline & Food Group & $\%$ of Total & Food Group & $\%$ of Total & Food Group & $\%$ of Total \\
\hline 1 & Infant formula & 26 & Growing-up milk & 20 & Eggs & 15 \\
\hline 2 & Eggs & 18 & Eggs & 16 & Pork & 10 \\
\hline 3 & Breast milk & 12 & Fish/shellfish/shrimps & 10 & Rice & 10 \\
\hline 4 & Rice & 7 & Pork & 9 & Fish/shellfish/shrimps & 10 \\
\hline 5 & Noodles & 6 & Rice & 9 & Growing-up milk & 9 \\
\hline 6 & Pork & 5 & Noodles & 6 & Milk & 7 \\
\hline 7 & Infant cereal & 5 & Milk & 5 & Noodles & 6 \\
\hline 8 & Fish/shellfish/shrimps & 5 & Pancakes/sesame seed cakes & 4 & Pancakes/sesame seed cakes & 5 \\
\hline 9 & Pancakes/sesame seed cakes & 3 & Chicken/duck & 3 & Chicken/duck & 5 \\
\hline 10 & Growing-up milk & 2 & Soy/tofu/meat substitutes & 2 & Soy/tofu/meat substitutes & 4 \\
\hline 11 & Milk & 2 & Bread/biscuits & 2 & Beef & 2 \\
\hline 12 & Bread/biscuits & 2 & Steamed bread & 1 & Bread/biscuits & 2 \\
\hline 13 & Steamed bread & 1 & - & & Other root vegetables & 2 \\
\hline 14 & Chicken/duck & 1 & - & & Nuts/seeds & 1 \\
\hline 15 & - & & - & & Steamed bread & 1 \\
\hline
\end{tabular}


Table 4 Sources of carbohydrate among infants and toddlers 6-35 months from the MING study

\begin{tabular}{|c|c|c|c|c|c|c|}
\hline \multirow[b]{2}{*}{ Rank } & \multicolumn{2}{|l|}{ Age 6-11 months } & \multicolumn{2}{|l|}{ Age $12-23$ months } & \multicolumn{2}{|l|}{ Age 24-35 months } \\
\hline & Food Group & $\%$ of Total & Food Group & $\%$ of Total & Food Group & $\%$ of Total \\
\hline 1 & Infant formula & 21 & Rice & 25 & Rice & 28 \\
\hline 2 & Rice & 16 & Growing-up milk & 19 & Noodles & 12 \\
\hline 3 & Breast milk & 16 & Noodles & 12 & Growing-up milk & 9 \\
\hline 4 & Noodles & 11 & Pancakes/sesame seed cakes & 7 & Pancakes/sesame seed cakes & 9 \\
\hline 5 & Infant cereal & 10 & Bread/biscuits & 4 & Bread/biscuits & 5 \\
\hline 6 & Pancakes/sesame seed cakes & 4 & Apples/applesauce & 4 & Apples/applesauce & 4 \\
\hline 7 & Apples/applesauce & 4 & Bananas & 3 & Bananas & 3 \\
\hline 8 & Bread/biscuits & 3 & Milk & 2 & Milk & 3 \\
\hline 9 & Bananas & 2 & Citrus fruits & 2 & Citrus fruits & 2 \\
\hline 10 & Steamed bread & 2 & Steamed bread & 2 & Soy/tofu/meat substitutes & 2 \\
\hline 11 & Millets & 1 & Millets & 2 & Steamed bread & 2 \\
\hline 12 & Growing-up milk & 1 & Infant cereal & 1 & Cakes/pies & 1 \\
\hline 13 & - & & Cakes/pies & 1 & Sweet potatoes/yams & 1 \\
\hline 14 & - & & Soy/tofu/meat substitutes & 1 & Millets & 1 \\
\hline
\end{tabular}

Table 5 Sources of fibre among infants and toddlers 6-35 months from the MING study

\begin{tabular}{|c|c|c|c|c|c|c|}
\hline \multirow[b]{2}{*}{ Rank } & \multicolumn{2}{|l|}{ Age 6-11 months } & \multicolumn{2}{|l|}{ Age $12-23$ months } & \multicolumn{2}{|l|}{ Age $24-35$ months } \\
\hline & Food Group & $\%$ of Total & Food Group & $\%$ of Total & Food Group & $\%$ of Total \\
\hline 1 & Apples/applesauce & 17 & Pancakes/sesame seed cakes & 11 & Soy/tofu/meat substitutes & 16 \\
\hline 2 & Infant formula & 12 & Apples/applesauce & 11 & Pancakes/sesame seed cakes & 11 \\
\hline 3 & Pancakes/sesame seed cakes & 7 & Soy/tofu/meat substitutes & 8 & Other root vegetables & 10 \\
\hline 4 & Rice & 7 & Growing-up milk & 8 & Apples/applesauce & 8 \\
\hline 5 & Noodles & 6 & Rice & 7 & Rice & 7 \\
\hline 6 & Bananas & 6 & Bananas & 6 & Bananas & 4 \\
\hline 7 & Pears & 5 & Pears & 5 & Pears & 4 \\
\hline 8 & Corn & 3 & Noodles & 5 & Nuts/seeds & 4 \\
\hline 9 & Cornmeal & 3 & Kiwi fruits & 4 & Noodles & 4 \\
\hline 10 & Spinaches & 3 & Nuts/seeds & 3 & Chinese cabbages & 3 \\
\hline 11 & Kiwi fruits & 3 & Chinese cabbages & 3 & Growing-up milk & 3 \\
\hline 12 & Soy/tofu/meat substitutes & 3 & Citrus fruits & 3 & Citrus fruits & 3 \\
\hline 13 & Steamed bread & 2 & Spinaches & 2 & Other leafy vegetables & 2 \\
\hline 14 & Chinese cabbages & 2 & Cornmeal & 2 & Spinaches & 2 \\
\hline 15 & Bread/biscuits & 2 & Other root vegetables & 2 & Corn & 2 \\
\hline 16 & Citrus fruits & 2 & Steamed bread & 2 & Carrots & 2 \\
\hline 17 & Carrots & 1 & Bread/biscuits & 2 & Bread/biscuits & 1 \\
\hline 18 & Other leafy vegetables & 1 & Other leafy vegetables & 2 & Coles & 1 \\
\hline 19 & Dragon fruits & 1 & Dried fruits & 2 & Steamed bread & 1 \\
\hline 20 & Other fruits & 1 & Corn & 1 & Sweet potatoes/yams & 1 \\
\hline 21 & Millets & 1 & Sweet potatoes/yams & 1 & Other fruits & 1 \\
\hline 22 & Other root vegetables & 1 & Peaches/nectarines/plums & 1 & - & \\
\hline 23 & - & & Green beans & 1 & - & \\
\hline 24 & - & & Carrots & 1 & - & \\
\hline
\end{tabular}


followed by pancakes/sesame seed cakes, rice, noodles, bananas. Among toddlers, in addition to apples/applesauce, pancakes/sesame seed cakes, and soy/tofu/meat substitutes were the most important sources of dietary fibre. Despite being commonly consumed, various leafy vegetables including Chinese cabbages and spinach are not significant contributors to dietary fibre among toddlers.

Infant formula and breast milk together contributed nearly $60 \%$ of the fat in the diets of infants $(32 \%$ and $28 \%$ respectively) (Table 6). Growing-up milk and milk together contributed 30 and $21 \%$ of fat among the younger and older toddlers respectively. Oil/other fats, pork were also in the top 5 infant sources of fat, and became more important in the diets of toddlers. By age 24 to 35 months, pork was the number one $(23 \%)$ and oil/ other fats the number two (17\%) source of fat. These two foods together contribute $38 \%$ of the fat in the diet of younger toddlers. Eggs were also major sources of fat among the children (Table 6). Cholesterol is not a concern among children in these age groups; however, top sources of cholesterol in the diet were eggs, fish/shellfish/shrimps and pork.

\section{Micronutrients}

The top 5 food sources of energy were also major contributors to the intakes of a number of vitamins and minerals as shown by Fig. 2 with more pronounced contributions seen among infants contributing from 79 to $53 \%$. The contribution of the top 5 food sources of energy to the intakes of micronutrients was reduced among older toddlers, however, still contributed $50 \%$ or more to most micronutrient intakes among younger toddlers (Fig. 2).
Infant formula and growing-up milk were the number one sources of iron among infants and toddlers, contributing nearly one third of the daily intake among infants, $27 \%$ to younger toddlers and $12 \%$ to older toddlers (Fig. 2 and Table 7). Rice was the number two source among both younger and older toddlers. Other important sources of iron were eggs, infant cereal, noodles and rice among infants, noodles and eggs among younger and older toddlers. Root vegetables and soy/tofu/meat became major sources of iron among older toddlers (Table 7).

Infant formula and growing-up milk were the number one sources of zinc among infants and younger toddlers (Fig. 2 and Table 8). Among older toddlers, rice was the number one source of zinc, followed by growing-up milk. Other important sources of zinc were breast milk, infant cereal and eggs among infants, eggs and pork among toddlers (Fig. 2 and Table 8). In addition, infant formula or growing-up milk was the number one source of calcium contributing $44 \%$ among infants, and nearly $50 \%$ among younger toddlers. Growing-up milk combined with other milk contributing $47 \%$ to calcium intake among older toddlers (Fig. 2 and Table 9). Other major sources of calcium were infant cereal and breast milk among infants and eggs and fish/shellfish/shrimps among toddlers (Table 9).

For selenium, eggs were the number one source among all children, followed by infant formula, noodles and fish/ shellfish/shrimps among infants, and fish/shellfish/shrimps, growing-up milk and noodles and pork among toddlers (Table 10). For sodium, the number one source was the salt added during home cooking contributing the vast majority: $60 \%$ of the total sodium intake among infants and about $80 \%$ among toddlers (Table 11). The number two sources

Table 6 Sources of fat among infants and toddlers 6-35 months from the MING study

\begin{tabular}{|c|c|c|c|c|c|c|}
\hline \multirow[b]{2}{*}{ Rank } & \multicolumn{2}{|l|}{ Age 6-11 months } & \multicolumn{2}{|l|}{ Age $12-23$ months } & \multicolumn{2}{|l|}{ Age 24-35 months } \\
\hline & Food Group & $\%$ of Total & Food Group & $\%$ of Total & Food Group & $\%$ of Total \\
\hline 1 & Infant formula & 32 & Growing-up milk & 25 & Pork & 23 \\
\hline 2 & Breast milk & 28 & Oil/other fats & 21 & Oil/other fats & 17 \\
\hline 3 & Eggs & 14 & Pork & 17 & Growing-up milk & 13 \\
\hline 4 & Oil/other fats & 8 & Eggs & 12 & Eggs & 12 \\
\hline 5 & Pork & 5 & Milk & 5 & Milk & 8 \\
\hline 6 & Infant cereal & 2 & Nuts/seeds & 3 & Nuts/seeds & 5 \\
\hline 7 & Bread/biscuits & 2 & Bread/biscuits & 3 & Chicken/duck & 4 \\
\hline 8 & Growing-up milk & 1 & Chicken/duck & 2 & Bread/biscuits & 3 \\
\hline 9 & Milk & 1 & Breast milk & 2 & Fish/shellfish/shrimps & 2 \\
\hline 10 & - & & Fish/shellfish/shrimps & 1 & Soy/tofu/meat substitutes & 2 \\
\hline 11 & - & & Rice & 1 & Rice & 1 \\
\hline 12 & - & & Infant formula & 1 & Yogurt & 1 \\
\hline 13 & - & & - & & Sausages & 1 \\
\hline
\end{tabular}




\section{6-11 months}

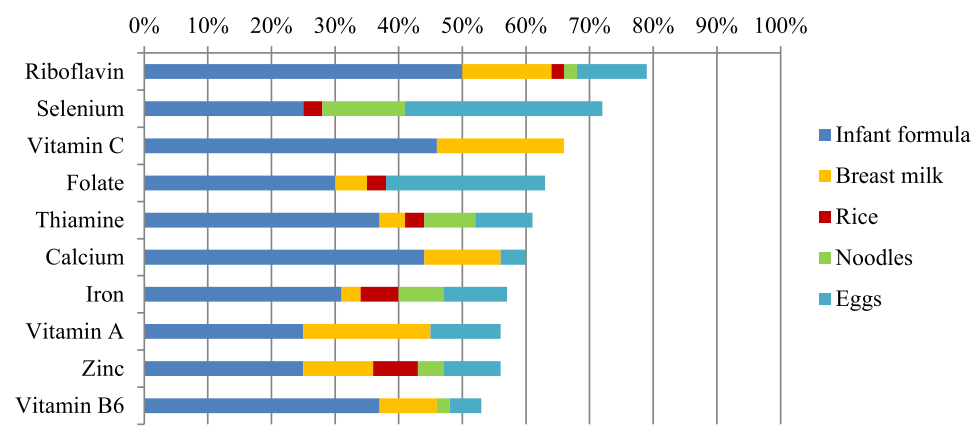

\section{2-23 months}

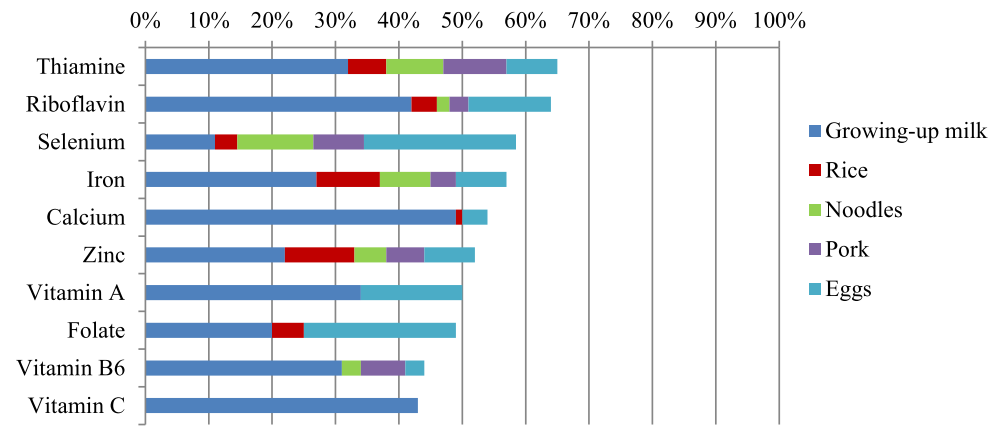

Fig. 2 Percent contribution of top 5 food sources of energy to intakes of micronutrients among infants and toddlers from the MING study

Table 7 Sources of iron among infants and toddlers 6-35 months from the MING study

\begin{tabular}{|c|c|c|c|c|c|c|}
\hline \multirow[b]{2}{*}{ Rank } & \multicolumn{2}{|l|}{ Age 6-11 months } & \multicolumn{2}{|l|}{ Age 12-23 months } & \multicolumn{2}{|l|}{ Age $24-35$ months } \\
\hline & Food Group & $\%$ of Total & Food Group & $\%$ of Total & Food Group & $\%$ of Total \\
\hline 1 & Infant formula & 31 & Growing-up milk & 27 & Growing-up milk & 12 \\
\hline 2 & Supplements & 13 & Rice & 10 & Rice & 11 \\
\hline 3 & Eggs & 10 & Noodles & 8 & Supplements & 11 \\
\hline 4 & Infant cereal & 8 & Eggs & 8 & Other root vegetables & 10 \\
\hline 5 & Noodles & 7 & Supplements & 5 & Soy/tofu/meat substitutes & 8 \\
\hline 6 & Rice & 6 & Pancakes/sesame seed cakes & 4 & Noodles & 7 \\
\hline 7 & Breast milk & 3 & Fish/shellfish/shrimps & 4 & Eggs & 7 \\
\hline 8 & Pancakes/sesame seed cakes & 2 & Pork & 4 & Pancakes/sesame seed cakes & 5 \\
\hline 9 & Apples/applesauce & 2 & Soy/tofu/meat substitutes & 3 & Pork & 4 \\
\hline 10 & Pork & 2 & Other root vegetables & 2 & Fish/shellfish/shrimps & 3 \\
\hline 11 & Growing-up milk & 2 & Apples/applesauce & 2 & Milk & 2 \\
\hline 12 & Organ meats & 1 & Oil/other fats & 2 & Spinach & 2 \\
\hline 13 & Spinach & 1 & Spinach & 2 & Apples/applesauce & 2 \\
\hline 14 & Millets & 1 & Millets & 1 & Bread/biscuits & 1 \\
\hline 15 & Soy/tofu/meat substitutes & 1 & Bread/biscuits & 1 & Oil/other fats & 1 \\
\hline 16 & - & & Chinese cabbages & 1 & Chicken/duck & 1 \\
\hline 17 & - & & Milk & 1 & Chinese cabbages & 1 \\
\hline 18 & - & & Organ meats & 1 & Beef & 1 \\
\hline
\end{tabular}


Table 8 Sources of zinc among infants and toddlers 6-35 months from the MING study

\begin{tabular}{|c|c|c|c|c|c|c|}
\hline \multirow[b]{2}{*}{ Rank } & \multicolumn{2}{|l|}{ Age 6-11 months } & \multicolumn{2}{|l|}{ Age $12-23$ months } & \multicolumn{2}{|l|}{ Age $24-35$ months } \\
\hline & Food Group & $\%$ of Total & Food Group & $\%$ of Total & Food Group & $\%$ of Total \\
\hline 1 & Infant formula & 25 & Growing-up milk & 22 & Rice & 13 \\
\hline 2 & Supplements & 16 & Supplements & 18 & Growing-up milk & 12 \\
\hline 3 & Breast milk & 11 & Rice & 11 & Supplements & 12 \\
\hline 4 & Infant cereal & 10 & Eggs & 7 & Pork & 8 \\
\hline 5 & Eggs & 9 & Pork & 6 & Eggs & 7 \\
\hline 6 & Rice & 7 & Fish/shellfish/shrimps & 5 & Milk & 5 \\
\hline 7 & Noodles & 4 & Noodles & 5 & Noodles & 5 \\
\hline 8 & Pork & 3 & Milk & 3 & Fish/shellfish/shrimps & 5 \\
\hline 9 & Pancakes/sesame seed cakes & 2 & Pancakes/sesame seed cakes & 3 & Pancakes/sesame seed cakes & 4 \\
\hline 10 & Growing-up milk & 2 & Soy/tofu/meat substitutes & 2 & Soy/tofu/meat substitutes & 4 \\
\hline 11 & Fish/shellfish/shrimps & 2 & Infant cereal & 1 & Beef & 3 \\
\hline 12 & Apples/applesauce & 1 & - & & Chicken/duck & 2 \\
\hline 13 & - & & - & & Bread/biscuits & 1 \\
\hline 14 & - & & - & & Nuts/seeds & 1 \\
\hline 15 & - & & - & & Other root vegetables & 1 \\
\hline
\end{tabular}

of sodium were infant formula, contributing $14 \%$ to the diets of infants and growing-up milk contributing 3-5\% to the diets of toddlers.

For all children in the study, infant formula and growingup milk were the number one sources of vitamin A, vitamin C, thiamine, riboflavin, vitamin B6 (Fig. 2 and Tables 12 and 13. Data for thiamine, riboflavin and vitamin B6 are not shown). Eggs were commonly eaten and were major sources of vitamin A, thiamine, riboflavin and folate. For folate, eggs were the number one source (Table 14). With age, the contribution of growing-up milk to vitamin $\mathrm{C}$ intake was reduced (Fig. 2 and Table 13) but citrus fruits began to make a contribution to vitamin $\mathrm{C}$ ranging from $4 \%$ among infants to 10 and $14 \%$ among younger and older toddlers respectively (Table 13). Among toddlers, Chinese cabbage was also an important source of vitamin $\mathrm{C}$ contributing about 7 to $10 \%$, indicating that Chinese cabbages were commonly consumed by this population.

Dietary supplements made substantial contributions to the overall intakes of several vitamins and minerals

Table 9 Sources of calcium among infants and toddlers 6-35 months from the MING study

\begin{tabular}{|c|c|c|c|c|c|c|}
\hline \multirow[b]{2}{*}{ Rank } & \multicolumn{2}{|l|}{ Age 6-11 months } & \multicolumn{2}{|l|}{ Age 12-23 months } & \multicolumn{2}{|l|}{ Age 24-35 months } \\
\hline & Food Group & $\%$ of Total & Food Group & $\%$ of Total & Food Group & $\%$ of Total \\
\hline 1 & Infant formula & 44 & Growing-up milk & 49 & Growing-up milk & 30 \\
\hline 2 & Supplements & 15 & Supplements & 13 & Milk & 17 \\
\hline 3 & Infant cereal & 13 & Milk & 10 & Supplements & 17 \\
\hline 4 & Breast milk & 12 & Eggs & 4 & Eggs & 5 \\
\hline 5 & Eggs & 4 & Fish/shellfish/shrimps & 4 & Fish/shellfish/shrimps & 4 \\
\hline 6 & Growing-up milk & 3 & Infant cereal & 2 & Yogurt & 3 \\
\hline 7 & Milk & 2 & Yogurt & 2 & Soy/tofu/meat substitutes & 3 \\
\hline 8 & Fish/shellfish/shrimps & 1 & Chinese cabbages & 2 & Chinese cabbages & 2 \\
\hline 9 & - & & Soy/tofu/meat substitutes & 2 & Other root vegetables & 2 \\
\hline 10 & - & & Other root vegetables & 1 & Citrus fruits & 2 \\
\hline 11 & - & & Rice & 1 & Rice & 2 \\
\hline 12 & - & & Citrus fruits & 1 & Coles & 2 \\
\hline 13 & - & & - & & Infant cereal & 2 \\
\hline 14 & - & & - & & Bread/biscuits & 1 \\
\hline 15 & - & & - & & Pancakes/sesame seed cakes & 1 \\
\hline
\end{tabular}


Table 10 Sources of selenium among infants and toddlers 0-35 months from the MING study

\begin{tabular}{|c|c|c|c|c|c|c|c|c|}
\hline \multicolumn{3}{|c|}{ Age 6-11 months } & \multicolumn{3}{|c|}{ Age $12-23$ months } & \multicolumn{3}{|c|}{ Age 24-35 months } \\
\hline Rank & Food Group & $\%$ of Total & Rank & Food Group & $\%$ of Total & Rank & Food Group & $\%$ of Total \\
\hline 1 & Eggs & 31.3 & 1 & Eggs & 23.7 & 1 & Eggs & 22.7 \\
\hline 2 & Infant formula & 24.7 & 2 & Fish/shellfish/shrimps & 18.8 & 2 & Fish/shellfish/shrimps & 14.8 \\
\hline 3 & Noodles & 12.6 & 3 & Growing-up milk & 11.3 & 3 & Noodles & 11.0 \\
\hline 4 & Fish/shellfish/shrimps & 6.6 & 4 & Noodles & 11.5 & 4 & Pork & 9.7 \\
\hline 5 & Pork & 4.4 & 5 & Pork & 7.7 & 5 & Growing-up milk & 6.3 \\
\hline 6 & Rice & 3.4 & 6 & Rice & 3.5 & 6 & Milk & 5.5 \\
\hline 7 & Bread/biscuits & 2.8 & 7 & Milk & 3.3 & 7 & Rice & 4.2 \\
\hline 8 & Steamed bread & 2.1 & 8 & Bread/biscuits & 3.0 & 8 & Chicken/duck & 4.2 \\
\hline 9 & Pancakes/sesame seed cakes & 1.9 & 9 & Pancakes/sesame seed cakes & 2.7 & 9 & Pancakes/sesame seed cakes & 3.4 \\
\hline 10 & Organ meats & 1.4 & 10 & Chicken/duck & 2.3 & 10 & Bread/biscuits & 2.9 \\
\hline 11 & Chicken/duck & 1.0 & 11 & Steamed bread & 1.8 & 11 & Steamed bread & 1.8 \\
\hline 12 & - & & 12 & Cakes/pies & 1.2 & 12 & Cakes/pies & 1.4 \\
\hline 13 & - & & & - & & 13 & Soy/tofu/meat substitutes & 1.1 \\
\hline 14 & - & & & - & & 14 & Beef & 1.1 \\
\hline
\end{tabular}

(Fig. 3). Supplements were the number two or number three sources of vitamin A among the children contributing between 22 to $25 \%$ (Fig. 3 and Table 12). Supplements were also the major sources of iron, zinc and calcium among all children (Fig. 3 and Tables 7, 8 and 9). To a lesser extent, supplements contributed to the intakes of thiamine, riboflavin, vitamin B6 and vitamin C (Fig. 3).

\section{Discussion}

To our knowledge, this was the first study conducted in China to describe, in detail, the sources of energy and nutrients from the diets of infants and toddlers. Our previous analyses of nutrient intakes among these children found potential risks for inadequate intakes of fat, vitamin B6, folate, iron and selenium and excessive intakes of vitamin A and sodium [18]. The present study provides further insights on those findings.

\section{Majority of energy and nutrients come from few foods}

The findings of the study show that relatively few foods provide the majority of energy and nutrients in the diets of young Chinese children. The top five foods for energy provided about $70 \%$ of energy among infants and more than $50 \%$ energy intake among toddlers. Infant formula and growing-up milk were important sources of many key nutrients. Indeed, in this study infant formula and growing-up milk made significant contributions to the intakes of all the nutrients described, and were the number one or two sources for most of the nutrients we assessed.

However, after the contribution from milks, the next two key contributors of energy were predominantly

Table 11 Sources of sodium among infants and toddlers 6-35 months from the MING study

\begin{tabular}{|c|c|c|c|c|c|c|}
\hline \multirow[b]{2}{*}{ Rank } & \multicolumn{2}{|l|}{ Age 6-11 months } & \multicolumn{2}{|l|}{ Age $12-23$ months } & \multicolumn{2}{|l|}{ Age 24-35 months } \\
\hline & Food Group & $\%$ of Total & Food Group & $\%$ of Total & Food Group & $\%$ of Total \\
\hline 1 & Salts & 60 & Salts & 80 & Salts & 77 \\
\hline 2 & Infant formula & 14 & Growing-up milk & 5 & Growing-up milk & 3 \\
\hline 3 & Eggs & 7 & Fish/shellfish/shrimps & 4 & Eggs & 3 \\
\hline 4 & Fish/shellfish/shrimps & 4 & Eggs & 3 & Fish/shellfish/shrimps & 3 \\
\hline 5 & Infant cereal & 2 & Milk & 1 & Milk & 2 \\
\hline 6 & Bread/biscuits & 2 & - & & Pork & 1 \\
\hline 7 & Noodles & 1 & - & & Bread/biscuits & 1 \\
\hline 8 & Oil/other fats & 1 & - & & Sausages & 1 \\
\hline 9 & Steamed bread & 1 & - & & - & \\
\hline 10 & Pork & 1 & - & & - & \\
\hline
\end{tabular}


Table 12 Sources of vitamin A among infants and toddlers 6-35 months from the MING study

\begin{tabular}{|c|c|c|c|c|c|c|}
\hline \multirow[b]{2}{*}{ Rank } & \multicolumn{2}{|l|}{ Age 6-11 months } & \multicolumn{2}{|l|}{ Age $12-23$ months } & \multicolumn{2}{|l|}{ Age $24-35$ months } \\
\hline & Food Group & $\%$ of Total & Food Group & $\%$ of Total & Food Group & $\%$ of Total \\
\hline 1 & Infant formula & 25 & Growing-up milk & 34 & Growing-up milk & 24 \\
\hline 2 & Supplements & 25 & Supplements & 25 & Eggs & 22 \\
\hline 3 & Breast milk & 20 & Eggs & 16 & Supplements & 22 \\
\hline 4 & Eggs & 11 & Organ meats & 6 & Carrots & 5 \\
\hline 5 & Organ meats & 8 & Spinach & 2 & Milk & 4 \\
\hline 6 & Infant cereal & 4 & Citrus fruits & 2 & Citrus fruits & 4 \\
\hline 7 & Spinach & 1 & Carrots & 2 & Spinach & 3 \\
\hline 8 & Carrots & 1 & Milk & 2 & Organ meats & 3 \\
\hline 9 & Growing-up milk & 1 & Breast milk & 2 & Broccoli & 2 \\
\hline 10 & - & & Broccoli & 2 & Chinese cabbages & 2 \\
\hline 11 & - & & - & & Pork & 1 \\
\hline 12 & - & & - & & Fish/shellfish/shrimps & 1 \\
\hline 13 & - & & - & & Other root vegetables & 1 \\
\hline 14 & - & & - & & Chicken/duck & 1 \\
\hline
\end{tabular}

refined carbohydrate containing foods, rice and noodles, which provided 17 to $25 \%$ of total energy intake. Given the low protein content of rice and noodles, the fact that these two foods, taken together, contributed about 13 to $16 \%$ of protein intake among the young children suggests that these foods were frequently consumed and consumed in a significant amount. Presently, the rice consumed in China is refined white rice that is not enriched or fortified. Noodles are also made of refined wheat flour that is not fortified. Therefore, they are

Table 13 Sources of vitamin C among infants and toddlers 6-35 months from the MING study

\begin{tabular}{|c|c|c|c|c|c|c|}
\hline \multirow[b]{2}{*}{ Rank } & \multicolumn{2}{|l|}{ Age 6-11 months } & \multicolumn{2}{|l|}{ Age 12-23 months } & \multicolumn{2}{|l|}{ Age 24-35 months } \\
\hline & Food Group & $\%$ of Total & Food Group & $\%$ of Total & Food Group & $\%$ of Total \\
\hline 1 & Infant formula & 46 & Growing-up milk & 43 & Growing-up milk & 26 \\
\hline 2 & Breast milk & 20 & Citrus fruits & 10 & Citrus fruits & 14 \\
\hline 3 & Infant cereal & 5 & Chinese cabbages & 7 & Chinese cabbages & 10 \\
\hline 4 & Citrus fruits & 4 & Kiwi fruits & 6 & Supplements & 5 \\
\hline 5 & Chinese cabbages & 3 & Other root vegetables & 4 & Other leafy vegetables & 5 \\
\hline 6 & Kiwi fruits & 3 & Spinach & 3 & Coles & 5 \\
\hline 7 & Apples/applesauce & 2 & Bananas & 3 & Spinach & 4 \\
\hline 8 & Supplements & 2 & Broccoli & 2 & Bananas & 3 \\
\hline 9 & Spinach & 2 & Apples/applesauce & 2 & Tomatoes/tomato sauce & 3 \\
\hline 10 & Growing-up milk & 2 & Other leafy vegetables & 2 & Broccoli & 3 \\
\hline 11 & Bananas & 2 & Tomatoes/tomato sauce & 2 & Apples/applesauce & 3 \\
\hline 12 & Other leafy vegetables & 1 & Coles & 2 & Potatoes & 2 \\
\hline 13 & - & & Supplements & 2 & Kiwi fruits & 2 \\
\hline 14 & - & & Potatoes & 1 & Other root vegetables & 2 \\
\hline 15 & - & & Breast milk & 1 & Carrots & 2 \\
\hline 16 & - & & Sweet potatoes/yams & 1 & Other fruits & 2 \\
\hline 17 & - & & - & & Jujube & 2 \\
\hline 18 & - & & - & & Milk & 1 \\
\hline 19 & - & & - & & Sweet potatoes/yams & 1 \\
\hline 20 & - & & - & & 100 juice & 1 \\
\hline
\end{tabular}


Table 14 Sources of folate among infants and toddlers 6-35 months from the MING study

\begin{tabular}{|c|c|c|c|c|c|c|}
\hline \multirow[b]{2}{*}{ Rank } & \multicolumn{2}{|l|}{ Age 6-11 months } & \multicolumn{2}{|l|}{ Age 12-23 months } & \multicolumn{2}{|l|}{ Age 24-35 months } \\
\hline & Food Group & $\%$ of Total & Food Group & $\%$ of Total & Food Group & $\%$ of Total \\
\hline 1 & Infant formula & 30 & Eggs & 24 & Eggs & 20 \\
\hline 2 & Eggs & 25 & Growing-up milk & 20 & Other root vegetables & 20 \\
\hline 3 & Organ meats & 7 & Citrus fruits & 6 & Growing-up milk & 9 \\
\hline 4 & Breast milk & 5 & Spinaches & 6 & Citrus fruits & 6 \\
\hline 5 & Spinaches & 5 & Rice & 5 & Rice & 5 \\
\hline 6 & Rice & 3 & Organ meats & 4 & Spinaches & 5 \\
\hline 7 & Citrus fruits & 2 & Other root vegetables & 3 & Coles & 5 \\
\hline 8 & Chinese cabbages & 2 & Coles & 3 & Soy/tofu/meat substitutes & 3 \\
\hline 9 & Infant cereal & 2 & Chinese cabbages & 2 & Pancakes/sesame seed cakes & 2 \\
\hline 10 & Coles & 2 & Pancakes/sesame seed cakes & 2 & Chinese cabbages & 2 \\
\hline 11 & Apples/applesauce & 2 & Nuts/seeds & 2 & Nuts/seeds & 2 \\
\hline 12 & Pancakes/sesame seed cakes & 1 & Soy/tofu/meat substitutes & 2 & Supplements & 2 \\
\hline 13 & Mangoes & 1 & Bananas & 2 & Milk & 2 \\
\hline 14 & Supplements & 1 & Apples/applesauce & 2 & Bananas & 1 \\
\hline 15 & Bananas & 1 & Milk & 2 & Bread/biscuits & 1 \\
\hline 16 & Growing-up milk & 1 & Bread/biscuits & 1 & Apples/applesauce & 1 \\
\hline 17 & - & & - & & Sweet potatoes/yams & 1 \\
\hline 18 & - & & - & & Yogurt & 1 \\
\hline 19 & - & & - & & Fish/shellfish/shrimps & 1 \\
\hline
\end{tabular}

relatively poor sources of many important nutrients. Due to the widespread consumption of rice and noodles in this population, rice actually was the top one or two sources for iron and zinc. In addition, noodles were also among the major sources for thiamine, iron and selenium. When foods that are poor sources of nutrients become major sources in the diet, it is quite reasonable to speculate that risk of nutrient shortfall could exist. A recent review reported that anaemia prevalence of children under 5 years old in China was $11.3 \%$ in 2005 [19] and the peak of anaemia prevalence was between infants aged 6 to 12 months [20].

In this study, growing-up milk remained to be one of the major contributors to energy and many nutrients among toddlers, which indicated that growing-up milk was commonly consumed among toddlers of the study. In comparison, in the diets of US infants and toddlers [6], the contribution of infant formula or growing-up milk to energy and nutrients declines steadily as children age and drops out of top five sources among toddlers. Optimally, when the intake of growing-up milk is reduced in older toddlers, it should be replaced with nutrient rich foods such as milk, eggs and meat, but in reality, the children were consuming a large portion of energy from rice and noodles, two nutrient poor foods. Education is needed on the nutrient rich foods that toddlers should be consuming, such as milk, meat and fish, vegetables and fruits, especially as the amount of growing-up milk, a major nutrient contributor, is reduced.

The fact that the majority of energy and nutrients come from few foods also implies that the variety of food consumed by these young children was limited. Eating a variety of food is essential to achieve adequate intake of macro-and micronutrients to meet nutritional needs. In addition, it is critical to expose infants to a wide variety of healthy foods, as it has been found that infants exposed to a variety of solid foods more readily accept new foods compared to infants exposed to a monotonous solid diet [21]. Food preferences established during childhood persists during adulthood [22]. Our findings point out the need to counsel caregivers of young children in China on how to select and serve a variety of nutrient rich foods to improve nutrient intakes of young children and teach healthy eating habits. This is especially important among the infants aged 6-11 months, but also for toddlers, as they are transitioning from reliance on infant formulas and growing-up milk to the family meals.

Another important finding of this study was that dietary supplements were significant contributors to the intakes of many nutrients, especially for the intakes of vitamin A, vitamin B6, calcium, iron and zinc (Fig. 3). This was particularly important for this population whose diets contained significant amounts of refined rice 


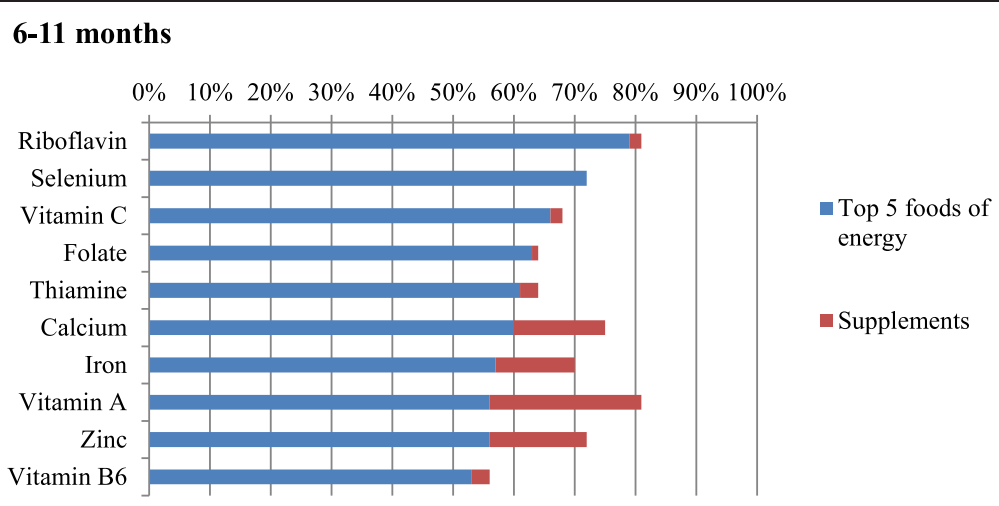

\section{2-23 months}

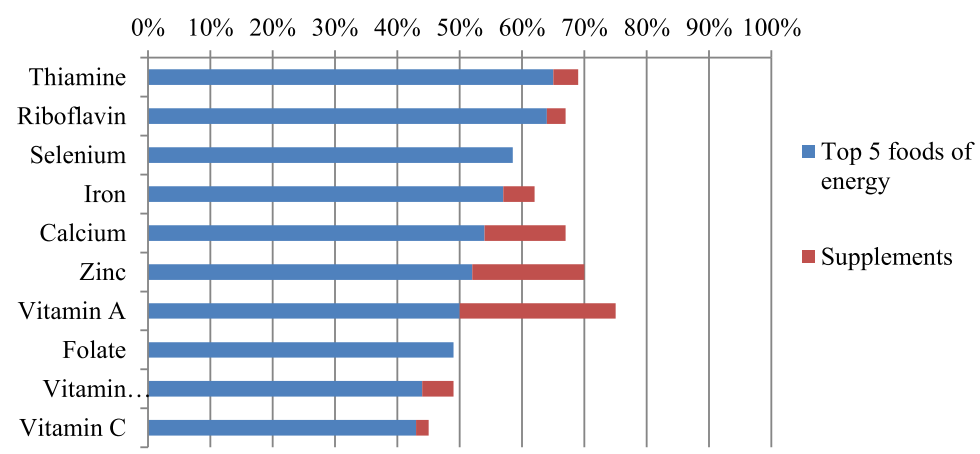

\section{4-35 months}

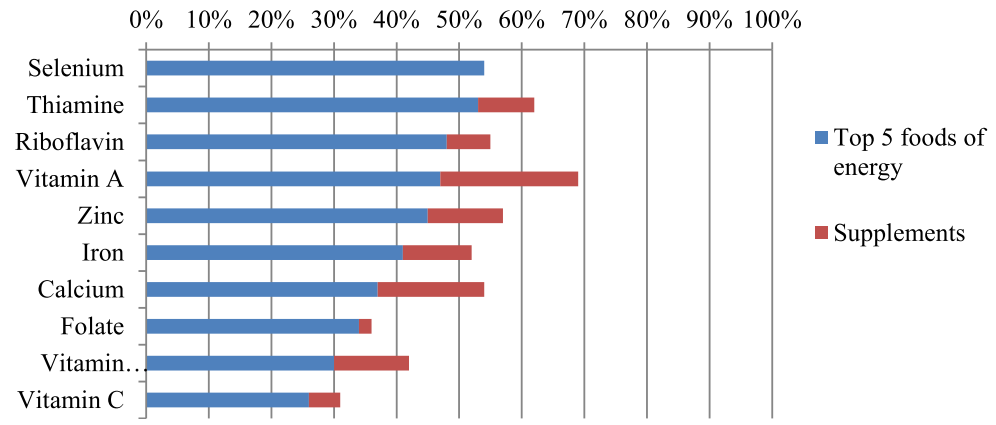

Fig. 3 Percent contribution of dietary supplements to micronutrient intakes among infants and toddlers from the MING study

and noodles. Indeed, although subclinical vitamin A deficiency has decreased from $40 \%$ to less than $10 \%$ from 1988 to 2009 but prevalence of marginal vitamin A deficiency (serum retinol level 0.70-1.05 $\mu \mathrm{mol} / \mathrm{l}$ ) was still 20 to $45 \%$ [19]. However, excessive intake of vitamin A was observed in our previous analysis on nutrient intakes of this population [18]. In this study, the contributions of supplements to vitamin A intake were substantial: 22 to $25 \%$ (Table 12). Although supplements may be beneficial to prevent nutrient deficiencies [23], it is also important to understand that the majority of nutrient intakes should be consumed as part of a normal diet composed of a variety of food groups and in that way the potential risk of excessive nutrient intakes can be avoided.

\section{Fruit and vegetable intakes needs improvement}

In this study, infant formula or growing-up milk was the number one source of vitamin $C$ for all age groups and it was remarkable to see that even among infants 12-23 months, growing-up milk contributed $43 \%$ of vitamin C. Chinese cabbages were also among the major contributors to vitamin $C$ intake reflecting its widespread consumption. However, the fact that a large part of the vitamin $C$ and folate intakes was from infant formula, growing-up milk or eggs suggests that the contribution of fruits and 
vegetables to micronutrient intakes in the diets of these Chinese infants and toddlers was not optimal. Fruits and vegetables are not only excellent natural sources of micronutrients $[24,25]$ but also associated with reduced risk of chronic diseases later in life [26-28]. Infancy and early childhood are critical periods for forming lifelong dietary habits [29]. Therefore, public health workers should encourage caregivers of young children to increase the consumption of fruits and vegetables among infants and toddlers to meet nutrient requirements as well as develop healthy dietary habits.

\section{Strength and limitation}

The strength of this study is that it used a much more detailed food group classification method than any previous studies conducted among infants and toddlers in China and so was able to describe the sources of energy and a number of key nutrients in detail.

However, we are aware that this study has some limitations. First, data for food consumption of these infants and toddlers relied totally on self-reports of caregivers and the information was only collected using a single 24-h dietary recall. The approach of using 1 day of intake to gain insight into food sources of energy and nutrients assumes that the diet on that day is representative or typical of habitual intake, and some evidence suggests that dayto-day variation is much less in the diets of infants and toddlers than among older children and adults [30]. Secondly, this study was conducted among infants and toddlers recruited from the maternal and child care centres in selected cities in China, including the three most industrialised cities, and was not a nationally representative sample. Therefore, sample weights or other sampling adjustments were not applied. Some children may come from better-off families indicated by the reported household income. Therefore the data may represent the children from more developed urban areas rather than the general population of infants and toddlers in China. Thirdly, although the subjects of the study were recruited from a wide-spread of geographic locations in China, food consumption of children from different regions could be different but this was not investigated in the present study.

\section{Conclusions}

This study provides important insights from an analysis of food sources of energy and nutrients in the diets of infants and toddlers recruited from the maternal and child care centres in 8 cities in China. The results show that few foods made up the core of the diets of infants and young toddlers and a large proportion of energy was from low-nutrient dense foods (rice and noodles), which potentially could lead to inadequate intakes of some key nutrients. The intakes of more nutrient dense foods including fruits and vegetables, milk and meat should be encouraged. Information from this study could be used for the development of various public health strategies to improve diet quality and address nutrient shortfalls in the diets of this vulnerable population.

\section{Competing interests}

The author(s) declare that they have no competing interests. The study was funded by the Nestle Nutrition Institute China and the Nestle Research Centre. It was a collaborative effort between Peking University School of Public Health and Nestle.

\section{Authors' contributions}

HW contributed to the data collection, performed the statistical analyses and drafted the manuscript; LD contributed to interpretation of the data and critical revision of the manuscript; YZ contributed to data collection and statistical analyses; GVP contributed to the data interpretation and revision of the manuscript; KR contributed to the conception and design of the study, interpretation of the data and critical revision of the manuscript; $Y Z$ contributed to the conception and design of the study and data collection; PW contributed to the conception and design of the study. All authors read and approved the final manuscript.

\section{Acknowledgements}

The authors thank the families who volunteered for this study, Laurence Li for project support and guidance, Celia Ning for project management and data collection and local project staff for recruitment and data collection.

\section{Author details}

${ }^{1}$ School of Public Health, Peking University, Beijing, China. ${ }^{2}$ Nestlé Research Centre, Lausanne, Switzerland. ${ }^{3}$ Nestlé R\&D Centre, Beijing, China. ${ }^{4}$ Nestlé Nutrition Global R\&D, Florham Park, NJ, USA.

Received: 29 April 2015 Accepted: 7 September 2015

Published online: 16 September 2015

\section{References}

1. Harding JE. The nutritional basis of the fetal origins of adult disease Int J Epidemiol. 2001;30(1):15-23.

2. Barker DJ, Fall CH. Fetal and infant origins of cardiovascular disease. Arch Dis Child. 1993;68(6):797-9.

3. Salvo D, Frediani JK, Ziegler TR, Cole CR. Food group intake patterns and nutrient intake vary across low-income Hispanic and African American preschool children in Atlanta: a cross sectional study. Nutr J. 2012;11:62.

4. Subar AF, Krebs-Smith SM, Cook A, Kahle LL. Dietary sources of nutrients among US children, 1989-1991. Pediatrics. 1998;102(4 Pt 1):913-23.

5. Stroehla BC, Malcoe LH, Velie EM. Dietary sources of nutrients among rural Native American and white children. J Am Diet Assoc. 2005;105(12):1908-16.

6. Fox MK, Reidy K, Novak T, Ziegler P. Sources of energy and nutrients in the diets of infants and toddlers. J Am Diet Assoc. 2006;106(1 Suppl 1):S28-42.

7. Sepp H, Abrahamsson L, Lennernas Junberger M, Risvik E. The contribution of food groups to the nutrient intake and food pattern among pre-scholl children. Food Qual Prefer. 2002;13:107-16.

8. De Keyzer W, Lin Y, Vereecken C, Maes L, Van Oyen H, Vanhauwaert E, et al. Dietary sources of energy and macronutrient intakes among Flemish preschoolers. Arch Public Health. 2011;69(1):5.

9. Li Y, Guo Z, Min P. Assessment of dietary energy intake on weaning infants aged 6-24 months. Acta Nutrimenta Sinica. 2011;33:616-8.

10. Geng Y, Han J, Li Y. Current situation of different fatty acid intake and its food source among children in China. Chinese Journal of School Health. 2011;32:530-1.

11. Gao P, Wang J, Li Y, Liang H, Chen D, Lv J, et al. Investigation on the dietary iron intake of infants from four month-old to one year-old in Shunyi District of Beijing. Wei Sheng Yan Jiu. 2012;41(4):576-8. 584.

12. Center of Disease Control Institute of Nutrition and Food Hygiene. China Food Composition. 1st ed. Beijng: Beijing Medical University Press; 2004.

13. Center of Disease Control Institute of Nutrition and Food Hygiene. China Food Composition. 2nd ed. Beijing: Beijing Medical University Press; 2009.

14. Nutrition Coordinating Center University of Minnesota. Revisiting vitamin A measurements. NDS Q. 2002;12(2). 
15. Butte NF, Fox MK, Briefel RR, Siega-Riz AM, Dwyer JT, Deming DM, et al. Nutrient intakes of US infants, toddlers, and preschoolers meet or exceed dietary reference intakes. J Am Diet Assoc. 2010;110(12 Suppl):S27-37.

16. Krebs-Smith SM, Cronin FJ, Haytowitz DB, Cook DA. Food sources of energy, macronutrients, cholesterol, and fiber in diets of women. J Am Diet Assoc. 1992;92(2):168-74.

17. Subar AF, Krebs-Smith SM, Cook A, Kahle LL. Dietary sources of nutrients among US adults, 1989 to 1991. J Am Diet Assoc. 1998;98(5):537-47.

18. Denney L, Vinyes Pares G, Zhang Y, Wang P, Reidy K. Nutrient intakes of infants and toddlers in China (MING study). Malaysian J Nutr. 2015;21 (Supplement):S31.

19. Wong AY, Chan EW, Chui CS, Sutcliffe AG, Wong IC. The phenomenon of micronutrient deficiency among children in China: a systematic review of the literature. Public Health Nutr. 2014;17(11):2605-18.

20. Chang S, He W, Jia F, Chen C. Analysis on the changes of nutritional status in China anemia status of children under 5 in China. Wei Sheng Yan Jiu. 2007;36(2):210-2.

21. Gerrish CJ, Mennella JA. Flavor variety enhances food acceptance in formula-fed infants. Am J Clin Nutr. 2001;73(6):1080-5.

22. Nicklaus S, Boggio V, Chabanet C, Issanchou S. A prospective study of food variety seeking in childhood, adolescence and early adult life. Appetite. 2005;44(3):289-97.

23. Siega-Riz AM, Estrada Del Campo Y, Kinlaw A, Reinhart GA, Allen LH, Shahab-Ferdows S, et al. Effect of supplementation with a lipid-based nutrient supplement on the micronutrient status of children aged 6-18 months living in the rural region of Intibuca. Honduras Paediatr Perinat Epidemiol. 2014;28(3):245-54.

24. U.S. Department of Health and Human Services. Dietary Guidelines for Americans 2005. Washington DC: US Government Printing Office; 2005

25. Wardlaw GM, Insel PM. Perspectives in nutrition. St. louis, Mosby: MosbyYear Book Inc.; 1996.

26. Law MR, Morris JK. By how much does fruit and vegetable consumption reduce the risk of ischaemic heart disease? Eur J Clin Nutr. 1998;52(8):549-56.

27. Joshipura KJ, Ascherio A, Manson JE, Stampfer MJ, Rimm EB, Speizer FE, et al. Fruit and vegetable intake in relation to risk of ischemic stroke. JAMA. 1999;282(13):1233-9.

28. Voorrips LE, Goldbohm RA, van Poppel G, Sturmans F, Hermus RJ, van den Brandt PA. Vegetable and fruit consumption and risks of colon and rectal cancer in a prospective cohort study: The Netherlands Cohort Study on Diet and Cancer. Am J Epidemiol. 2000;152(11):1081-92.

29. Mikkila V, Rasanen L, Raitakari OT, Pietinen P, Viikari J. Consistent dietary patterns identified from childhood to adulthood: the cardiovascular risk in Young Finns Study. Br J Nutr. 2005;93(6):923-31.

30. Lanigan JA, Wells JC, Lawson MS, Cole TJ, Lucas A. Number of days needed to assess energy and nutrient intake in infants and young children between 6 months and 2 years of age. Eur J Clin Nutr. 2004;58(5):745-50.

\section{Submit your next manuscript to BioMed Central and take full advantage of:}

- Convenient online submission

- Thorough peer review

- No space constraints or color figure charges

- Immediate publication on acceptance

- Inclusion in PubMed, CAS, Scopus and Google Scholar

- Research which is freely available for redistribution 